\title{
NOVEL ATHEIS KARYA ACHDIAT KARTA MIHARDJA SEBAGAI MATERI PEMBELAJARAN SASTRA : ANALISIS PSIKOLOGI SASTRA DAN NILAI PENDIDIKAN
}

\author{
Haryo Seto Saktiono, Herman J. Waluyo, Sri Hastuti \\ Universitas Sebelas Maret \\ Surel: haryoseto114@gmail.com
}

\begin{abstract}
: the objectives of this research is to describe: (1) id psychology on the main character in Atheis novel by Achdiat Karta Mihardja; (2) ego psychology on the main character in the Atheis novel; (3) super-ego psychology on the main character in the Atheis novel; (4) the educational value contained in the Atheis novel; (5) its relevance as teaching material in learning literature appreciation in high school.This research uses descriptive qualitative method with psychology approach of literature. This research uses descriptive qualitative method with psychology approach of literature. The data obtained by researchers coming from Atheis novel, interviews with writers, lecturers of Indonesian language studies program, teachers and students. The validity of data is obtained through triangulation theory. Data were analyzed using analysis techniques interactive.The conclusions of this study were (1) the psychology of the main character in the Atheis novel by Achdiat Karta Mihardja is a Hasan character who suffers from psychiatric disorder that is the uncertainty of choosing religious belief (2) there are eleven grades of character traits contained in Atheis novel, they are religious values, tolerance, hard work, social caring, curiosity, friendship, responsibility, self-reliance, peace, discipline, like to read (3) Atheis novel is relevant to the literary learning material in senior high school because it contains many moral messages and good character education value for students.
\end{abstract}

Keywords: novel, literary psychology, educational value, learning literature.

Abstrak: tujuan penelitian ini untuk mendeskripsikan: (1) kejiwaan Id pada tokoh utama dalam novel Atheis karya Achdiat Karta Mihardja; (2) kejiwaan Ego pada tokoh utama dalam novel Atheis karya Achdiat Karta Mihardja; (3) kejiwaan Super ego pada tokoh utama dalam novel Atheis karya Achdiat Karta Mihardja; (4) nilai pendidikan yang terkandung dalam novel Atheis karya Achdiat Karta Mihardja; (5) relevansinya sebagai materi ajar dalam pembelajaranapresiasi sastra di SMA.Penelitian ini menggunakan metode deskriptif kualitatif dengan pendekatan psikologi sastra. Data yang diperoleh peneliti berasal dari novel Atheis karya Achdiat Karta Mihardja, hasil wawancara dengan sastrawan, dosen Progam Studi Bahasa Indonesia, guru dan siswa-siswi SMA N 1 Gemolong. Teknik pengambilan sampel dilakukan dengan menggunakan purposive sampling. Validitas data diperoleh melalui triangulasi teori. Teknik analisis data menggunakan teknik analisis Interaktif.Simpulan penelitian ini adalah (1) kejiwaan tokoh utama dalam novel Atehis karya Achdiat Karta Mihardja adalahtokoh Hasan yang mengalami gangguan kejiwaan yaitu kebimbangan untuk memilih kepercayaan agama (2) terdapat sebelas nilai pedidikan karakter yang terkandung dalam novel Atheis karya Achdiat Karta Mihardja, nilai-nilai tersebut adalah nilai religius, toleransi, bekerja keras, peduli sosial, rasa ingin tahu, bersahabat, tanggung jawab, mandiri, cinta damai, disiplin, gemar membaca (3) novel Atheis karya Achdiat Karta Mihardja relevan dengan materi pembelajaran sastra di SMA karena banyak mengandung pesan moral dan nilai pendidikan karakter yang baik bagi siswa. 
Kata kunci: novel, psikologi sastra, nilai pendidikan pembelajaran sastra di SMA

\section{PENDAHULUAN}

Pengertian sastra dalam bahasa Indonesia tidak jauh berbeda dengan bahasa-bahasa Eropa, seperti literature (Inggris), literatur (Jerman), literatuur (Belanda), litterature (Perancis), yang semuanya diturunkan dari litteratura (bahasa latin). Menurut asalnya, kata litteratura (latin) ini dipakai dalam pengertian tata bahasa dan puisi. Seorang litteratus adalah orang yang tahu tata bahasa dan puisi. Secara umum dalam bahasa-bahasa Eropa modern, kata yang diturunkan dari litteratura (Latin) itu menunjukkan arti: "segala sesuatu yang tertulis, pemakaian bahasa dalam bentuk tertulis" (Teeuw, 1984:22).

Teeuw dalam Sastra dan Ilmu sastra (1988) menyebutkan bahwa kata "literature" dalam bahasa Inggris berasal dari bahasa Yunani, yang berarti huruf. Dalam penggunaan masa lalu, literature mengacu pada susunan kata dalam tata bahasa dan puisi. Orang yang memahami tata bahasa dan puisi disebut dengan literature. Dalam bahasa Perancis, kata "letter" mengacu pada kata sastra dalam bahasa Indonesia. Kata Perancis itu hampir mirip dengan kata dalam bahasa Belanda, yakni geletterd. Dua kata itu memiliki makna yang sama, yakni orang yang berada dan memiliki kemahiran khusus di bidang sastra. Berbeda dengan kata Perancis dan Belanda, kata Jerman adalah schrifftum dan dichtung. Pengertian schrifftum mengacu pada segala hal yang tertulis sementara dichtung terbatas pada tulisan yang tidak langsung berkaitan dengan fakta-fakta aktual sehingga bisa dikatakan imajinasi. Seorang penyair dalam bahasa Jerman disebut dengan der Dichter atau die Dichterin. Hal itu sekurang-kurangnya dijelaskan oleh A. Hauken (1992) dalam Kamus Jerman Indonesia. Rene Wellek dan Austin Warren dalam Teori Kesusastraan (1993) menyebutkan bahwa sastra adalah segala sesuatu yang tertulis atau tercetak.

Fiksi, sering pula disebut cerita rekaan, ialah cerita dalam prosa, hasil olahan pengarang berdasarkan pandangan, tafsiran, dan penilaiannya tentang peristiwa-peristiwa yang pernah terjadi, ataupun pengolahan tentang peristiwaperistiwa yang hanya berlangsung dalam khayalannya (Simposium, 1966:117). 
Pada rumusan di atas jelas bahwa fiksi itu bisa berupa suatu penceritaan tentang tafsiran atau imajinasi pengarang tentang peristiwa yang pernah terjadi atau hanya terjadi dalam khayanalan saja.

Sebagaimana kita pahami, novel merupakan suatu karya fiksi, yaitu karya dalam bentuk kisah atau cerita yang melukiskan tokoh-tokoh dan peristiwaperistiwa rekaan. Atau menurut pengertian yang diberikan oleh Yelland (1983) bahwa fiksi berarti "that which is invented, as istinguished from the which is true." Sebuah novel bisa saja memuat tokoh-tokoh dan peristiwa-peristiwa nyata, tetapi permuatan tersebut biasanya hanya berfungsi sebagai bumbu belaka dan mereka dimasukkan dalam rangkaian cerita yang bersifat rekaan atau dengan detail rekaan. Walaupun peristiwa dan tokoh-tokohnya bersifat rekaan, mereka memiliki kemiripan dengan kehidupan sebenarnya, mereka merupakan "cerminan kehidupan nyata". Pantas diperdebatkan karena masalah kemiripan ini sangat bervariasi antara satu novel dengan novel yang lain. Terlepas dari silang pendapat tersebut, kemiripan dengan kehidupan nyata ini sudah menjadi ciri pembeda (distinctive feature) novel dari karya-karya sastra lainnya, seperti dari roman atau hikayat.

Psikologi secara etimologis berasal dari kata psyche dari bahasa Yunani kuno yang artinya napas atau jiwa; logi dari kata logos yang artinya ilmu, jadi psikologi artinya ilmu jiwa. Dalam bahasa Inggris istilah psikologi disebut psychology dan dalam bahasa Indonesia padanannya adalah ilmu jiwa atau ilmu kerohanian. Banyak pengertian definisi mengenai psikologi yang dikemukakan oleh para ahli. Worth dan Margius (dalam Bimo Walgito, 1997: 8) berpendapat bahwa psikologi itu mempelajari aktivitas-aktivitas individu, pengertian aktivitas dalam arti luas, baik aktivitas motorik, kognitif maupun emosional. Selain itu, Branca (dalam Bimo Walgito, 1997: 8) berpendapat bahwa psikologi merupakan ilmu tentang tingkah laku. Psikologi adalah suatu cabang dari ilmu pengetahuan yang mempelajari, menyelidiki, atau membahas fungsi-fungsi kejiwaan dari orang yang sehat. Dengan kata lain psikologi mempelajari aktivitas kehidupan kejiwaan dari orang yang normal (Fudyartanta, 2011: 1). Psikologi ditafsirkan sebagai lingkup gerak jiwa, konflik batin tokoh-tokoh dalam sebuah karya sastra secara 
tuntas. Dengan demikian, pengetahuan psikologi dapat dijadikan sebagai alat bantu dalam menelusuri sebuah karya sastra secara tuntas (Darmanto Jatman, 1985: 164).

\section{METODE PENELITIAN}

Penelitian ini dilakukan selama tujuh bulan dengan menggunakan dokumen novel Atheis yaitu bulan Oktober sampai bulan April. Pendekatan yang digunakan dalam penelitian ini berupa penelitian kualitatif dengan jenis penelitian deskriptif. Data dikumpulkan dengan cara mengkaji dokumen yang berupa novel yang berjudul Atheis karya Achdiat Karta Mihardja yang berjumlah 250 lembar dan diterbitkan oleh Balai Pustaka pada tahun 2009. Selanjutnya, data divalidasi dengan menggunakan teknik tri anggulasi sumber. Teknik analisis data pada penelitian ini menggunakan teknis analisis interaktif.

\section{HASIL PENELITIAN DAN PEMBAHASAN}

\section{Kejiwaan Tokoh Utama Dalam Novel Atheis Karya Achdiat Karta Mihardja}

Id (terletak di bagian tak sadar) yang merupakan reservoir pulsi dan menjadi sumber energi psikis.Id merupakan energi psikis dan naluri yang menekankan manusia agar memenuhi kebutuhan dasar seperti misalnya kebutuhan: makan, seks, menolak rasa sakit atau tidak nyaman. Menururt Freud, id berada dialam bawah sadar, tidak ada kontak dengan realitas. Cara kerja id berhubungan dengan prinsip kesenangan, yakni selalu mencari kenikmatan dan selalu menghindari ketidaknyamanan.

Ego (terletak di antara alam sadar dan tak sadar) yang bertugas sebagai penengah yang mendamaikan tuntutan pulsi dan larangan superego.Ego (das ich) dikatakan mengikuti prinsip kenyataan (realitas) dan beroperasi menurut proses sekunder. Untuk sementara waktu prinsip kenyataan menunda prinsip kenikmatan, meskipun pada akhirnya prinsip kenikmatan akan terpenuhi ketika objek yang dibutuhkan telah ditemukan dan dengan demikian tegangan dapat direduksikan (Hall dan Lindzey, 1993: 66). Proses sekunder adalah berpikir realistis. Dengan proses sekunder, ego menyusun rencana untuk memuaskan kebutuhan dan kemudian menguji rencana ini, biasanya melalui suatu tindakan untuk melihat apakah rencana itu berhasil atau tidak. Orang yang lapar berpikir di mana ia dapat menemukan makanan dan kemudian pergi ke tempat itu (Hall dan Lindzey, 1993: 66). 
Superego (terletak sebagian di bagian sadar dan sebagian lagi di bagian tak sadar) bertugas mengawasi dan menghalangi pemuasaan sempurna pulsi-pulsi tersebut yang merupakan hasil pendidikan dan identifikasi pada orang tua.Superego mengacu pada moralitas dalam kepribadian. Superego sama halnya dengan "hati nurani" yang mengenal nilai baik dan buruk (conscience). Melalui superego seorang manusia dapat mengambil kesimpulan mengenai sesuatu yang baik dan mana yang buruk. Superego berkembang dari pola-pola pengalaman, penghargaan, hukuman yang diinternalisasikan sejak kanak-kanak hingga dewasa (Olson dan Hergenhahn, 2011: 55).

Hasan adalah salah satu tokoh dalam novel atheis yang memiliki rasa keingintahuan yang sangat tinggi. Dalam novel atheis telah digambarkan mengenai karakter tokoh utama yaitu Hasan, bahwa tokoh Hasan digambarkan sebagai seorang yang alim, taat beribadah, dan memiliki rasa keingintahuan yang sangat tinggi. Karakter Hasan yang taat beribadah digambar oleh pengarang dalam novel atheis, dimana bentuk taat beribadah dari tokoh Hasan berupa tidak pernah lupa dengan sholat dan selalu berzikir setelah selesai melaksanakan sholat. Karakter Hasan dengan rasa keingintahuan yang sangat tinggi juga telah digambarkan dalam novel atheis, ketika Hasan penasaran terhadap Kartini yaitu sosok wanita yang cantik jelita dan sosok wanita yang telah berhasil mengambil hati Hasan.

Tokoh Hasan adalah salah satu tokoh dalam novel atheis yang memiliki super ego yang tinggi, dimana dalam hal ini terlihat ketika Hasan menuntut ilmu agama seperti kedua orang tua dan ingin mengislamkan temannya Rusli dan Kartini. Kepribadian super ego yang dominan dalam diri Hasan juga dibenarkan oleh Bapak Arief guru SMA N 1 Gemolong. Bapak Arief mengatakan bahwa kepribadian super ego dalam tokoh Hasan dapat dilihat ketika Hasan ketika usianya masih kecil ingin menuntut ilmu agama seperti kedua orang tuanya. Selain itu sastrawan Yant Mujiyanto juga mengatakan bahwa karakter supe ego terlihat ketika Hasan ingin mengislamkan teman-temannya yang atheis yaitu Rusli dan Kartini.

Tokoh utama lain yang memiliki super ego adalah tokoh Kartini. Super egoKartini terlihat ketika Kartini mencoba meredam emosi Hasan karena cemburu dengan Anwar, dengan cara membuka pintu yang telah dikunci oleh Kartini. Selain itu juga karena malu dengan tetangga karena suara keras dari Hasan, sehingga Kartini mau tidak mau membuka pintu kamarnya. Kejadian tersebut berlangsung di rumah Hasan dan Kartini, setelah Kartini pulang dari belanja. 


\section{Nilai-nilai Pendidikan Karakter Dalam Novel Atheis Karya Achdiat Karta Mihardja}

Makna nilai yang diacu dalam sastra menurut Herman J Waluyo (2002: 27) adalah kebaikan yang ada dalam makna karya sastra bagi kehidupan seseorang. Berkaitan dengan nilai didik dan nilai edukatif dalam karya sastra, Suyitno (1986:3) mengatakan bahwa sastra sebagai hasil olahan sastrawan,yang mengambil bahan dari segala permasalahan dalam kehidupan dapat memberikan pengetahuan yang tidak dimiliki oleh pengetahuan yang lain.

Nilai-nilai pendidikan karakter dapat diperoleh manusia melalui berbagai hal diantaranya melalui pemahaman dan penikmatan sebuah karya sastra. Nilai-nilai itu mengungkapkan perbuatan yang dipuji atau dicela, pandangan hidup mana yang dianut atau dijauhi, dan hal-hal apa yang dijunjung tinggi yang berkaitan dengan moral, sosial, religi, dan budaya dalam kehidupan manusia.Pendapat lain mengenai pendidikan karakter datang dari Ratna (2014: 132) yang menyatakan bahwa pendidikan karakter merupakan proses pembentukan kepribadian, kejiwaan, dan psike, sekaligus hubungan seimbang dengan struktur kejasmanian, dalam rangka mengantisispasi pengaruh dari luar yang bersifat negatif.

Nilai pendidikan karakter yang dirumuskan oleh para pakar pendidikan melalui Kementerian Pendidikan Nasional berjumlah delapan belas poin. Nilai-nilai tersebut tercantum di dalam sistem pendidikan karakter yang bertujuan untuk mengembangkan potensi peserta didik agar menjadi manusia yang beriman dan bertakwa kepada Tuhan YME, peduli sosial, mandiri, bertanggung jawab, bekerja keras, komunikatif dan lai-lain. Dari kedelapan belas poin menurut Kementerian Pendidikan Nasional, ada sebelas poin yang terdapat dalam novel Atheis. Berikut ini penjelasan dari sebelas poin nilai-nilai pendidikan karakter yang terdapat dalam novel atheis:

Nilai-nilai pendidikan karakter yang paling menonjol dalam novel Atheis adalah nilai pendidikan karakter religius, nilai-nilai ini sangat erat dilukiskan dalam penggambaran tokoh yaitu Hasan, Rusli, Kartini, Anwar, Ayah Hasan dan Bibi Hasan. Tak hanya nilai pendidikan karakter religius, akan tetapi juga nilai-nilai yang lain seperti nilai peduli sosial, nilai cinta damai, nilai disiplin dan lain sebagainya.

Nilai religius dalam novel atheis dilukiskan pada tokoh Hasan yang selalu rajin melaksanakan ibadah sholat dan tak lupa setelah melakukan ibadah sholat Hasan melakukan ibadah zikir. Di dalam ajaran agama Islam, ibadah sholat wajib adalah ibadah yang wajib dilakukan oleh umat muslim karena hukumnya wajib. Selain ibadah sholat wajib dan zikir 
tokoh Hasan juga digambarkan telah melakukan sholat malam dan nyanyian-nyanyian puji Tuhan, hal ini menandakan nilai religius dalam novel atheis sangat kental.

Nilai toleransi dalam novel atheis, digambarkan melalui hubungan percakapan yang terjadi antara tokoh Hasan dan Rusli. Hasan dan Rusli adalah sahabat dari kecil, dan mereka terpisah namun akhirnya bertemu kembali. Kedua tokoh tersebut terlihat saling menghargai perbedaan pendapat yang terjadi, terkadang tokoh Hasan dalam hati kecilnya tidak terima pendapat Rusli mengenai tidak adanya Tuhan dan juga kepintaran manusia yang tanpa batas.

Nilai disiplin dalam novel atheis, dicerminkan oleh tokoh Hasan yang selalu tepat waktu dalam melaksanakan ibadah sholat. Karena hasan sudah rajin sejak kecil, maka Hasan pun tidak pernah merasakan keberatan dalam melaksanakan ibadah sholat wajib. Tak hanya itu Hasan juga disiplin melaksanakan ibadah sholat sunnah, yaitu sholat tengah malam.

Nilai kerja keras dalam novel atheis dicerminkan melalui tokoh Rusli dan juga Bibi Hasan. Kedua tokoh tersebut menggambarkan nilai-nilai kerja keras, dimana kedua tokoh tersebut berjuang keras mencari nafkah untuk kehidupan sehari hari. Nilai kerja keras pada tokoh Rusli, terlihat ketika Rusli berjuang keras mencari nafkah dengan menjadi buruh pelabuhan, sopir taksi sampai berdagang kecil-kecilan. Nilai kerja keras selain tokoh Rusli juga terlihat pada tokoh Bibi Hasan, dimana Bibi Hasan berjuang keras mencari nafkah untuk mencukupi kebutuhan sehari-hari. Nilai kerja keras pada Bibi Hasan terlihat ketika Bibi Hasan mencari nafkah dengan mengontrakan rumahnya dan berdagang kecil-kecilan, hal tersebut terpaksa dilakukannya karena Bibi Hasan seorang janda yang tak punya apa-apa selain rumahnya.

Nilai rasa ingin tahu dalam novel atheis dilukiskan pada tokoh Ayah Hasan, dimana Ayah Hasan memiliki rasa ingin tahu terhadap sesuatu yang dilakukan oleh Haji Dahlan. Rasa ingin tahu yang dimiliki oleh Ayah Hasan bermula ketika Haji Dahlan menginap di rumah Hasan, Ayah Hasan selalu memperhatikan apa yang di lakukan oleh Haji Dahlan. Peristiwa itu terjadi pada saat Ayah Hasan dan Haji Dahlan sepulang sholat jum'at dari masjid, dimana Ayah Hasan berkata pada Haji Dahlan "Kakak lihat adik selalu memetik tasbih". Dari perkataan Ayah Hasan tersebut terlihat jelas bahwa, Ayah Hassan ingin tahu apa yang sedang dilakakukan oleh Haji Dahlan. Selain tokoh Ayah Hasan, tokoh lain yang menggambarkan nilai rasa ingin tahu adalah Anwar. Rasa ingin tahu yang dimiliki Anwar adalah rasa ingin tahu terhadap keberadaan Embah Jambrong, kejadian ini berada di desa Panyeredan pada malam hari. 
Nilai komunikatif atau bersahabat dalam novel atheis dilukiskan pada tokoh Hasan dan Rusli, dimana tokoh Hasan dan Rusliterlihat sekali mereka sedang asyik berbincangbincang di rumah Rusli. Dalam hal ini menandakan bahwa Hasan telah diterima dengan baik oleh Rusli, terbukti dengan Hasan berbincang-bincang di rumah Rusli. Hasan dan Rusli adalah sahabat sejak kecil, oleh karena itu juga Hasan dapat diterima baik oleh Rusli

Nilai gemar membaca dalam novel atheis dilukiskan pada tokoh Rusli, dimana di rumah Rusli banyak sekali buku-buku bacaan politik. Hal tersebut menandakan bahwa Rusli adalah tokoh yang suka membaca. Selain buku politik ada juga buku bacaan dengan berbahasa Inggris, dengan jumlah yang tidak sedikit pula di rumahnya.

Nilai peduli sosial dalam novel atheis dilukiskan pada tokoh Rusli, dimana Rusli membantu Hasan pada waktu Hasan sedang muntah muntah di rumah Kartini. Rusli terlihat membantu Hasan dengan memijit-mijit pundak Hasan, dan memijit pula pada leher Hasan. Selain itu nilai peduli sosial juga terlihat pada tokoh Kartini, dimana Kartini membantu Hasan dengan mengkompres kepala Hasan yang sedang sakit pada waktu itu. Peristiwa tersebut terjadi di rumah Kartini setelah mereka melakukan makan bersama, dan faktor penyebabnya karena Hasan mengira bahwa masakan yang disajikan di rumah Kartini adalah masakan restoran china.

Nilai mandiri dalam novel atheis dilukiskan pada tokoh Hasan, dimana Hasan terlihat melakukan tugas sendiri tanpa meminta bantuan dari orang lain. Nilai mandiri ini terlihat ketika Hasan bekerja di jawatan air Kotapraja, dimana Hasan terlihat menyelesaikan tugasnya dengan baik dan tanpa meminta bantuan dari orang lain.

Nilai cinta damai dalam novel atheis dilukiskan pada tokoh Hasan dan Rsuli, dimana Hasan dan Rusli memberikan sebuah penghargaan berupa perkataan yang menyenangkan hati dan tepuk tangan kepada Kartini.Kartini mendapat penghargaan dari Hasan dan Rusli, karena kepandaian Kartini dalam memainkan pianonya.Nilai tanggung jawab dalam novel atheis dilukiskan pada tokoh Hasan. Pada saat itu Hasan terlihat melakukan kesalahan di Rumah Rusli, dimana Hasan telah memecahkan jambangan milik Rusli. Akan tetapi nilai tanggung jawab telah digambarkan melalui tokoh Hasan, yaitu dengan berusaha membersihkan pecahan-pecahan jambangan milik Rusli.Dosen Sastra Prodi Pendidikan Bahasa Indonesia, menyatakan bahwa nilai-nilai yang paling terlihat dalam novel atheis adalah nilai-nilai religius. Hal ini sependapat dengan Sastrawan Yant Mujiyanto danbapak Arief selaku guru di SMA N 1 Gemolong 
Relevansi Novel Atheis Karya Achdiat Karta Mihardja Dengan Pembelajaran Sastra di SMA

Novel Atheis karya Achdiat Karta Mihardja merupakannovel yang mengandung nilai-nilai religius, nilai-nilai peduli sosial, dan nilai-nilai pendidikan lainnya yang dapat dijadikan teladan bagi siswa. Novel ini dapat dimanfaatkan sebagai bahan ajar apresiasi sastra di SMA khususnya kelas XI, karena pada usia siswa tersebut sudah dianggap mampu untuk membedakan mana yang baik dan mana buruk bagi hidupnya.

Apabila novel atheis dipakai dalam pembelajaran apresiasi sastra, maka novel atheis dirasa dapat membentuk karakter siswa yang baik. Selain itu novel atheis juga bisa di menjadi pelindung bagi siswa, dimana pada era zaman sekarang ini banyaknya hiburanhiburan yang dirasa tidak baik bagi kehidupan siswa. Sebagai contoh hiburan-hiburan pada zaman sekarang ini antara lain: televis dengan acara yang tidak baik, game, handphone dan lain sebagainya.

Kelebihan lain dari novel atheis selain dari nilai pendidikan karakternya adalah bahasa yang digunakan dirasa mudah untuk dipahami. Bahasa yang digunakan dalam novel atheis tidak berbelit belit seperti karya sastra pada umumnya, sehingga dirasa cocok untuk pembelajaran apresiasi sastra bagi siswa SMA kelas XI. Walau pun bahasa yang digunakan mudah dipahami, akan tetapi pasti ada beberapa kata yang mungkin sukar dimengerti oleh siswa. Hal tersebut bukan bertujuan untuk menyulitkan siswa, akan tetapi hal tersebut dapat menambah pengetahuan bagi siswa mengenai kosakata baru.

Bapak Arief selaku guru mata pelajaran Bahasa Indonesia berpendapat bahwa novel ini relevan jika digunakan sebagai materi pembelajaran Bahasa dan Sastra Indonesaia. Novel ini bagus digunakan untuk materi ajar karena nilai-nilai pendidikan yang bagus dan juga ceritanya yang menarik. Selain itu novel "Atheis" memiliki daya tarik sendiri yaitu jalan ceritanya yang selalu menarik perhatian para pembaca dengan teka-teki yang disuguhkan dalam cerita, sehingga para pembaca merasa tertarik untuk membaca dan mengikuti alurnya sampai tuntas. Selain guru, ada salah seorang sastrawan yang diwawancari oleh penulis, ia berpendapat bahwa novel ini sangat menyentuh sekali bagi saya atau pembaca yang lain, karena novel ini mengkisahkan sebuah cerita yang sangat indah dan juga alurnya sangat menarik walaupun novel ini keluaran tahun lama tetapi tetap asik dibaca sampai sekarang. Selain itu novel ini juga relevan jika dipakai untuk materi ajar karena nilai-nilai pendidikan yang disajikan didalamnya (sastrawan Yant Mujiyanto). 


\section{SIMPULAN}

Tokoh Hasan memiliki Id yang sangat tinggi, hal ini digambarkan ketika Hasan penasaran dengan Kartini yaitu sesosok wanita yang cantik jelita yang telah merebut hatinya. Selain itu Hasan juga memiliki superego yang tinggi, hal ini dapat dilihat ketika Hasan menuntut ilmu seperti kedua orang tuanya. Kartini juga mempunyai superego yang tinggi, hal ini dapat dilihat ketika Kartini mencoba meredadm emosi Hasan yang cemburu terhadap Anwar.Nilai-nilai pendidikan karakter yang terdapat dalam novel Atheis sangatlah banyak, dimana dalam novel Atheis terdapat sebelas nilai pendidikan karakter. Nilai-nilai pendidikan karakter tersebut terdiri dari: nilai religius, nilai toleransi, nilai kerja keras, nilai peduli sosial, nilai rasa ingin tahu, nilai bersahabat atau komunikatif, nilai tanggung jawab, nilai mandiri, nilai cinta damai, nilai disiplin, dan nilai gemar membaca.

Novel Atheis karya Achdiat Karta Mihardja relevan dengan pembelajaran sastra di SMA, diaman sekolah menggunakan kurikulum 2013. Faktor pendukung novel Atheis dapat dijadikan contoh novel dalam pembelajaran sastra antara lain: bahasa yang digunakan merupakan bahasa yang mudah dipahami, terdapat banyak sekali nilai-nilai pendidikan karakter yang dianggap dapat membentuk karakter siswa dengan baik, alur cerita yang menarik dan tentunya tidak mengandung unsur SARA.

\section{DAFTAR PUSTAKA}

Atar, M. Semi. (1993). Anatomi Sastra. Padang: Angkasa Raya

Aziez, Furqonul dan Hasim, Abdul. (2010). Menganalisis Fiksi. Bogor: Ghalia Indonesia

Emzir, dan Rohman, Saiful. (2015). Teori dan Pengajaran Sastra. Jakarta: PT Raja Grafindo Persada

Guntur, Henry Tarigan. (2015). Dasar-dasar psiko sastra. Bandung: ANGKASA

Minderop, Albertine. (2013). Psikologi Sastra karya sastra, metode, teori, dan contoh kasus. Jakarta: Yayasan Pustaka Obor Indonesia Ratna, N. K. (2009). Teori, Metode, dan Teknik Penelitian Sastra. Yogyakarta: Pustaka Pelajar.

Sehandi, Yohanes. (2015). Mengenal 25 Teori Sastra. Yogyakarta: Ombak

Teeum, A. (2016). Sastra dan Ilmu Sastra. Bandung: PT. Dunia Pustaka Jaya 